\title{
PELUANG DAN TANTANGAN SUMBER DAYA MANUSIA DI ERA DISRUPSI
}

\author{
Lia Muliawaty \\ Fakultas Ilmu Sosial dan Ilmu Politik, Universitas Pasundan \\ Kota Bandung, Jawa Barat, Indonesia \\ lia.muliawaty@unpas.ac.id
}

\begin{abstract}
ABSTRAK
Era dekade saat ini telah terjadi banyak perubahan mendasar pada berbagai sektor, antara lain ekonomi, teknologi, dan politik. Bahkan krisis ekonomi yang belakangan terjadi telah menekan banyak organisasi untuk memikirkan kembali prioritas -prioritas mereka. Oleh karena itu, terdapat dorongan untuk melakukan pembentukan kembali bisnis dan teknologinya. Terjadi perubahan besar dalam pekerjaan saat ini, yaitu dari peralihan dari sektor manufaktur dan pertanian menjadi industri jasa dan telekomunikasi. Faktor -faktor pendorongnya, antara lain kian menipisnya sumber daya alam dan bahkan beberapa negara tidak memilikinya. Sebaliknya, terdapat perkembangan pesat di sektor teknologi. Penemuan produk-produk teknologi baru telah menyebabkan produk teknologi lama menjadi usang, tidak terpakai lagi karena digantikan dengan yang baru tersebut. Contohnya personal computer (PC) digantikan dengan telepon pintar (smart phone). Selanjutnya telepon pintar digunakan untuk berbagai keperluan, misalnya pelayanan publik on line. Fenomena di atas adalah sebuah inovasi disruptif yang diciptakan oleh Clay Christensen pada tahun 1997. Inovasi disrupsi juga berdampak terhadap Sumber Daya Manusia dalam Manajemen (MSDM). Paradigma bar adalah sebuah pemimpinial yang berbasis teknologi modern, khususnya aplikasi komputer dan internet karena lebih praktis, efisien dan efektif. Disamping itu, penggunaan teknologi tersebut bertujuan untuk menghadapi kompetisi di sektor ketenagakerjaan di ASEAN, sebagai konsekuensi MEA, maupun menyongsong SDM di Abad ke-21. Saat ini peringkat SDM Indonesia berada pada urutan ke lima setelah negara Singapura, Brunei Darussalam, Malaysia, dan Thailand. Melalui inovasi disrupsi diharapkan dapat menghadapi kedua tantangan tersebut. Selain itu, inovasi disrupsi merupakan sebuah tantangan karena memunculkan sebuah paradigma baru, yaitu MSDM yang berbasis teknologi dan inovatif serta pembentukan SDM yang kompeten di bidangnya.
\end{abstract}

Kata Kunci: Disrupsi, Inovasi, Manajemen Sumber Daya Manusia, Teknologi.

\section{ABSTRACT}

In the current decade, there have been many fundamental changes in various sectors, including economy, technology and politics. Even the recent economic crisis has put pressure on many organizations to rethink their priorities. Hence, there is an impetus for reshaping the business and technology. There are major changes in employment today, namely from a shift from the manufacturing and agriculture sectors to the service and telecommunications industries. The driving factors include the depletion of natural resources and even some countries do not have them. On the other hand, there have been rapid developments in the technology sector. The discovery of new technological products has caused old technology products to become obsolete, no longer used because they are replaced by new ones. For example the personal computer $(P C)$ is replaced by a smart phone (smart phone). Furthermore, smart phones are used for various purposes, for example on line public services. The above phenomenon is a disruptive innovation created by Clay Christensen in 1997. Disruption innovation also has an impact on Human Resources in Management (HRM). The bar paradigm is a leader based on modern technology, especially computer and internet applications because it is more practical, efficient and effective. In addition, the use of this technology aims to face competition in the labor sector in ASEAN, as a consequence of the AEC, as well as welcoming HR in the 21st Century. Currently, Indonesia's HR ranking is in fifth place after Singapore, Brunei Darussalam, Malaysia, and Thailand. Through innovation, disruption is expected to face these two challenges. In addition, disruption innovation is a challenge because it raises a new paradigm, namely technology-based and innovative HRM and the formation of competent human resources in their fields.

Keywords: Disruption, Innovation, Human Resource Management, Technology 


\section{Kebijakan: Jurnal Ilmu Administrasi \\ Volume 10, Nomor 1, Januari 2019 \\ E-ISSN: 2656-2820 \\ P-ISSN 1829-5762}

\section{PENDAHULUAN}

Globalisasi telah menyebabkan banyak perubahan mendasar pada berbagai sektor, seperti pada sector ekonomi, teknologi, dan politik. Dampak yang paling kuat adalah sektor ekonomi. Tetapi dampak tersebut juga telah menyebabkan berbagai perubahan di sektor-sektor lainnya, seperti pada Sumber Daya Manusia yang terkelola atau di sebut manajemen sumber daya manusia (MSDM) Munculnya sebuah paradigma baru bahwa peranan manusia adalah suatu kenyataan yang merupakan arah paling strategis dan sebagai sebuah keunggulan kompetitif. Seperti yang dinyatakan oleh Cadwell (2004) bahwa manusia adalah sebuah aset dan dasar keunggulan kompetitif dari organisasi: "... managing people as assets that are fundamental to the competitive advantage of organization" (Amstrong, 2009: 6). Oleh karena itu, pegawai/pegawai adalah sebuah potensi yang dikelola dengan baik dan tepat melalui MSDM dapat memberikan hasil yang kompetitif. Pandangan baru mengenai peranan Sumber Daya Manusia (SDM) sebagai salah satu keuntungan kompetitif sebuah organisasi dinyatakan pula oleh Mathis dan Jackson (2005): "As human resources have become viewed as more critical to organizational success, many organizations have realized that it is the people in an organization that can provide a competitive advantage"(Mathis dan Jackson, 2005: 4). Juga dijelaskan bahwa penggunaan manusia dalam organisasi dapat menyediakan sebuah keunggulan kompetitif, baik domestik maupun luar negeri. "Organizational human resources have grown as a strategic emphasis because effective use of people in the organization can provide a competitive advantage both domestically and abroad". Sebenarnya pandangan ini sudah lama dikenal: "The idea that human resources can become a source of competitive advantage for the organization is not new" (de Pablos dan Lytras, 2008: 48).

Perubahan peran manusia, yang dinilai sebagai aset sebuah organisasi telah mendorong perubahan dalam prakteknya terciptanya sumber daya manusia menjadi lebih profesional. Hal ini disebabkan oleh dinamika yang terjadi di lingkungan internal maupun eksternal sebuah organisasi. Salah satu diantaranya adalah pengaruh teknologi: "Today, we"ve seen that trens like globalization, indebtedness, and technology confront employers with new challanges, such as squeezing more profits from operations" (Dessler, 2013: 17). Saat ini peranan produk-produk teknologi, misalnya komputer dan internet, telah memainkan peran penting dalam praktek manajemen sumber daya manusia, sehingga berbagai kegiatan menjadi lebih efektif, dan efisien. Produk teknologi adalah sebuah potensi untuk digunakan dalam penerapan pengelolaan sumber daya manusia. Disisi lain, organisasi berharap agar para pemimpinnya dapat mengatasi tantangan-tantangan ini: "Employers expect their human resource managers to have what it takes to address these challenges" (Dessler, 2013: 17).

Paradigma baru dalam sebuah organisasi publik ataupun swasta akan menimbulkan berbagai tantangan, diantaranya kendala di dalam merubah tata kelola organisasi yang sudah usang menjadi tata kelola yang baru (up date) karenanya perubahan ini sangat berkaitan dengan aspek manusia. Penggunaan teknologi modern termasuk mahal terutama bagi sebuah organsasi yang skala kecil dan menengah. Faktor lainnya adalah disrupsi (gangguan) yang menyebabkan percepatan teknologi, yaitu produk-produk teknologi lama digantikan dengan yang baru. Contoh disrupsi yang jelas adalah teknologi komputer, yaitu ketika fungsi personal computer (PC) sebagai peralatan yang membantu sumber daya manusia organisasi telah digantikan dengan komputer jinjing (laptop), dan selanjutnya terakhir diganti dengan gadget. Kini pengiriman surat melalui mesin faximili dianggap tidak praktis dan tidak ekonomis jika dibandingkan dengan produk-produk teknologi mutakhir yang disebutkan sebelumnya, yang pada masanya mesin mesin itu digunakan untuk pengiriman surat. 


\section{Kebijakan: Jurnal Ilmu Administrasi \\ Volume 10, Nomor 1, Januari 2019 \\ E-ISSN: 2656-2820 \\ P-ISSN 1829-5762}

Mesin tersebut sudah mengalami disrupsi dengan peralatan perkantoran yang baru, misalnya dengan menggunakan fasilitas Whatsapp (WA). Pada dasarnya disrupsi telah menyebabkan produk teknologi lama menjadi usang, tidak dapat digunakan, dan biaya operasionalnya tinggi. Situasi di mana pergerakan dunia industri atau persaingan kerja tidak lagi linear. Perubahannya sangat cepat, fundamental dengan mengacak-acak pola tatanan lama untuk menciptakan tatanan baru. Misalnya MOOC, singkatan dari Massive Open Online Course serta AI (Artificial Intelligence). MOOC adalah inovasi pembelajaran daring yang dirancang terbuka, dapat saling berbagi dan saling terhubung atau berjejaring satu sama lain.

\section{METODE}

Penelitian ini menggunakan metode kualitatif. Sedangkan jenis penelitiannya adalah survey, yaitu:" Jika kita bermaksud mengumpulkan data yang relative terbatas dari sejumlah kasus yang relative besar jumlahnya, metode yang kita dapat gunakan adalah survey. Metode ini menekankan lebih pada penentuan informasi tentang variable daripada informasi tentang individu" (Sevilla et al., 1993:76). Tujuan dari survey adalah sebagai berikut:" Untuk mengukur gejala-gejala yang ada tanpa menyelidiki kenpa gejala-gejala tersebut ada (exist). Di dalam penelitian yang demikian ini, kita tidak perlu memperhitungkan hubungan antara variable-variabel. Tujuan pokok kita adalah menggunakan data yang kita peroleh untuk memecahkan masalah, daripada untuk menguji hipotesis" (Sevilla et al., 1993:76). Data penelitian menggunakan data sekunder seperti kepustakan, referensi jurnal dan hasil penelitian.

\section{PEMBAHASAN}

\section{Manajemen Sumber Daya Manusia}

Pengertian dari Manajemen Sumber Daya Manusia (MSDM) bersifat dinamis dan terdiri dari beragam definisi maupun perspektif. Menurut Senyucel/bahwa MSDM memiliki banyak definisi:"There are countless definitions of what HRM is or should be and there is not one definition that can define what HRM exactly is". Selanjutnya ia menjelaskan bahwa MSDM bersifat multi disipliner organisasi yang terdiri dari berbagai bidang:" HRM is multidisciplinary organizational function that draws theories and ideas from various field such as management, psychology, sociology and economies" (Senyucel, 2009:14). Selain itu, terdapat interpretasi berbeda mengenai MSDM. Menurut pendapat Storey (1992) bahwa MSDM terdiri dari berikut ini:" The differences in the interpretation of HRM have created two different schools of thought: soft and hard variants of HRM. Soft and hard HRM are also often defined as two main models of HRM" (Senyucel, 2009:14). Joshi mendefinisikan MSDM terdiri dari seluruh upaya, ketrampilan atau kemampuan semua orang yang bekerja untuk organisasi: "The "human resource' of an organization is composed of all the efforts, skills or capabilities of all people who work for the organization. Some organizations may call this "human resource' as "staff' or "workforce' or "personnel' or "employees', but the basic meaning remains the same. All those who work for an organization are workers" (Joshi, 2013: 9).

Amstrong mendefinisikan MSDM melalui sebuah pendekatan yang strategis, terintegrasi dan saling bertalian secara logis: "Human resource management (HRM) is a strategic, integrated and coherent approach to the employment, development and well being of the people working in organization"(Amstrong, 2009: 4). Pendapat Beer (1984) MSDM adalah menyangkut seluruh seluruh keputusan manajemen dan tindakan yang menyebabkan hubungan antara organisasi dengan pegawaipegawai: "Human resource management involve all management decisions and action that affect the nature of the relationship between the organization and its employees - its human resources". Guest 


\section{Kebijakan: Jurnal Ilmu Administrasi \\ Volume 10, Nomor 1, Januari 2019 \\ E-ISSN: 2656-2820 \\ P-ISSN 1829-5762}

(1987) berpendapat bahwa MSDM terdiri dari sejumlah kebijakan yang dirancang untuk memaksimalkan organisasi: "HRM comprises a set of policies designed to maximize organizational integration, employee commitment, flexibility and quality of work"(Amstrong, 2009: 4). Sedangkan L.L Bean mendefinisikan MSDM secara singkat, yaitu terdiri dari orang yang secara ditugaskan untuk mencapai tujuan organisasi:

"An organization consists of people with formally assigned roles who work together to achieve the organization's goals" (Dessler, 2013: 4). Menurut Dessler MSDM meliputi beberapa proses berikut:"Human resources management is the process of acquiring, training, appraising, and compensating employees, and of attending to their labor relations, health and safety, and fairness concerns"(Dessler, 2013: 4). Pengertian MSDM yang dikemukakan oleh Dessler sifatnya lebih luas, beragam, dan kompleks. Hal ini sebagai gambaran dari kondisi MSDM modern, yaitu mengenai: 1) Planning; 2) Organizing; 3) Staffing; 4) Leading; dan 5) Controlling (Dessler, 2013: 4). Perkembangan dan perubahan Manajemen Sumber Daya Manusia (MSDM) disebabkan oleh berbagai sektor, seperti dinyatakan berikut: "Development in the economic, technological and political context the last two decade have positioned human resources in a critical position when it comes to building innovative capabilities in the firm"'(Nielsen, 2016: 6). Menurut Wang dan Ellinger (2011) pengaruh lainnya tetapi paling kuat adalah globalisasi: "Globalization is a central contextual driver of the increasingly strategic importance of human capabilities in firms" (Nielsen, 2016: 7). "Human Resources (HR) management deals with the design of formal systems in an organization to ensure the effective and efficient use of human talent to accomplish organizational goals. In an organization, the management of human resources means that they must be recruited, compensate, trained, and developed" (Mathis dan Jackson, 2005:4). Menurut Guest (1987) dan Hendry (1995) bahwa:" Modern human resource management emphasizes the importance of the intentional link between firm strategy and human resource management. Focus is set on planning and organizing the work process and building employee commitment related to the aims and values of the firm. Flexibility and quality in the employment system is also important"(Nielsen, 2016: 9). MSDM menghadapi beberapa tantangan berikut: 1) Economic and technological change; 2) Workforce availability and quality concern; 3) Demographics and diversity issues; dan 4) Organizational restructuring (Mathis dan Jackson, 2005: 4).

\section{Inovasi}

Mengenai definisi inovasi menurut Thompson (1995) adalah:"Innovation as the "generation, acceptance and implementation of new ideas, process, products, or services."; Zaltzman et al. (1973) mendefinisikan sebagai: "Idea, practice or material artefact perceived as new by the relevant unit of adoption (Madsen dan Ulhoi, 2005:489) Namun membedakan kedua jenis inovasi tersebut tidak mudah seperti dinyatakan oleh Sneep (1991) bahwa: "The distinction between incremental and radical innovation is difficult, as there is no absolute measure for intrinsic newness. Intrinsic newness relates to the scientific knowledge component of technology, whereas architevturality refers to the organisational component (i.e. how knowledge, artefact and auxiliaries are organized and combined in a new way that changes existing patterns" (Madsen dan Ulhoi, 2005:490)

Menurut Faberberg et al. (2005) bahwa inovasi adalah:"... innovation has become more and more important as a strategic clue to handle scarce resource and competition pressure as well as economic instability" (Nielsen, 2016: 6); Selanjutnya Nielsen dan Rasmussen (2011) menjelaskan cara membangun inovasi, yaitu:"...building innovative capabilities require active creation, coordination, and absorption of useful knowledge related to the deployment of the human resources in the organization and thus a cohesive operational management approach to learning. Most often learning 


\section{Kebijakan: Jurnal Ilmu Administrasi \\ Volume 10, Nomor 1, Januari 2019 \\ E-ISSN: 2656-2820 \\ P-ISSN 1829-5762}

in organizations and work has been approached without direct consideration on how to integrate it in the management of human resources. The outcome of learning, however, has long been considered relevant for management approaches as knowledge management"'(Nielsen, 2016: 1). Storey (1994) menyatakan bahwa:" Human resources management is a group of theories with various hard and soft approaches, which has developed continously since the eighties, mainly in relation to the changing conditions and challenges of the firms" (Nielsen, 2016: 9).

Inovasi adalah salah satu aspek penting dalam sebuah organisasi, "The main reason for this respond to environmental challenges faster and to exploit new products and market opportunities better then noninnovative companies" (Jimenez and Valle, 2007: 83). Peranan manusia atau pegawai adalah aset dan sebagai nilai kompetisi: "Human Resources, from the resource-based perspective, are key assets and sources of competitive advantage for the firm" (Jimenez and Valle, 2007: 83). "Innovation, and the company"s overall performance, depend on the extent to which managers can mobilize all of the knowledge resources held by individuals and teams within the company and turn these resources in value-creating activities" (Jimenez and Valle, 2007: 84). "Innovation has been conceptualized in a variety of ways in the literature, depending on the perspective from which it has been studied"(Jimenez and Valle, 2007: 84). "It has been considered as a process, a result, or both, and different types of innovation have been distiguished.

Menurut pendapat Damanpour dan Gopalakrishnan (1998) bahwa:" Innovation could be understood as the adoption of a new idea or behavior in an organization (Jimenez and Valle, 2007: 84). "Most of the definitions of innovation share the idea that innovation is related to the generation of knowledge, which may be developed into new products, processes, and services"(Jimenez and Valle, 2007: 84). "In terms of their radicalness, innovations can be broadly classified as incremental or radical" (Jimenez and Valle, 2007: 84). "Radical innovations produce fundamental changes in the activities of the organization, and represent a clear departure from existing practices. Incremental innovations include other changes in products and processes, such as changes that are "insignificant", minor, or do not involve sufficient degree of novelty, and result in a lesser degree of departure from existing practices"(Jimenez and Valle, 2007: 84).

\section{Inovasi Disrupsi}

Christensen berpendapat bahwa istilah disrupsi harus dilihat sebagai proses di mana organisasi kecil (sebagai pendatang) mampu menantang organisasi petahana (incumbent) yang sudah mapan dengan menawarkan teknologi baru - seringkali dengan harga lebih rendah - ke segmen masyarakat yang diabaikan:" Disruption should be seen as a process whereby small companies (entrants) are able to challenge established incumbent firms by offering new technology - often at a lower price - to overlooked customer segments"(Pérez et al., 2017:98); Definisi inovasi disrupsi adalah tidak menghadirkan produk yang lebih baik kepada masyarakat tetapi mereka mengganggu dengan memperkenalkan produk dan layanan yang tidak sebaik produk yang tersedia saat itu:" Disruptive innovations, in contrast, don "t attempt to bring better products to established customers in existing markets. Rather, they disrupt and redefine that trajectory by introducing products and services that are not as good as currently available products" (Christensen dan Raynor,2003:34).

Disrupsi terdiri dari dua jenis, yaitu:"1) New-market disruptions, dan 2) Low-end disruptions. Many disruptions are hybrids, combining new-market and low-end approaches" (Christensen dan Raynor,2003:45-47). ( Knight menyatakan bahwa inovasi disrupsi membawa produk yang lebih sederhana, terjangkau, dan lebih nyaman untuk dipasarkan. Disrupsi biasanya mengalahkan pemimpin pasar. Inovasi disrupsi sering kali melibatkan model bisnis baru"(Knight, 2005:17); "Inovasi disrupsi adalah sebuah adaptasi sederhana untuk teknologi yang ada, yang menarik bagi 


\section{Kebijakan: Jurnal Ilmu Administrasi \\ Volume 10, Nomor 1, Januari 2019 \\ E-ISSN: 2656-2820 \\ P-ISSN 1829-5762}

masyarakat yang tidak tertarik dengan produk sebelumnya" (Cowden dan Alhorr, 2013:359); "Konsep "teknologi disrupsi" atau " inovasi yang mengganggu " mengacu pada isu-isu kunci dalam industri dan struktur organisasi, proses bisnis dan alokasi sumber daya yang membatasi organisasi ketika berurusan dengan teknologi yang tidak sesuai dengan model bisnis mereka yang sudah mapan." (Madjdi and Hüsig, 2011: 15-16); Inovasi disrupsi pada dasarnya adalah menemukan teknologi baru berbiaya rendah :" The key is to find a low-cost emerging technology that is rapidly improving and match it with a solution that meets the disruptive business model (Eggers et al., 2012: 21).

Pada dasarnya ada tiga aktor yang terlibat dalam proses disrupsi, yaitu: "There are at least three types of actors involved in disruption, the entrants, the incumbents and the customers"(Habtay and Holm èn:4 ). Pendatang baru (entrants) akan melakukan disrupsi pada pihak petahana (incumbent) dengan cara membawa model bisnis baru atau produk baru.

\section{Teknologi}

Produk teknologi dapat memfasilitasi implementasi manajemen pengetahuan dalam sebuah organisasi: "Many analysts believe that the emergence of tachnologies such as the internet, mobile telephones and knowledge-based systems will facilitate the sharing of knowledge and assist in the implementation of knowledge management programs"(Soliman dan Spooner, 2000: 341). Pengetahuan berbasis teknologi informasi telah meningkatkan praktek manajemen sumber daya manusia yang semakin maju"The commercial emergence of knowledge based information technology represents a tremendous opportunity to enhance the practice of human resource management" (Soliman dan Spooner, 2000: 341).

Pengertian teknologi dalam konteks manajemen sumber daya manusia adalah: "The intentional use of knowledge and skills to extend the limited capabilities of human beings in normally referred to as technology" (Madsen dan Ulhoi, 2005: 489). Michie dan Archibugi (1995) menyatakan bahwa: "Another central driver is technology development" Greenan dan Walkowiak (2005) menyatakan bahwa:" Technology is a classic determinant of work organization and the use of human potentials. The important new development is, however, that relations between employee and work techniques" (Nielsen, 2016: 7)."The new technologies bring opportunities for desentralization of decisions and development of local solutions but also increasing interdependency and dynamics between business units"(Nielsen, 2016: 7)."Without information and communication technology it would be impossible for firms to distribute in global value chains" (Nielsen, 2016: 7).

Inovasi disrupsi pada teknologi komputer tidak sepenuhnya positif tetapi terdapat sisi negative sebagai dapat perkembangannya yang sangat cepat. Salah satu masalah paling kritis yang kita hadapi pada abad ke-21 adalah bahwa teknologi saat ini melampaui kemampuan kita sebagai penggunanya: "One of the most critical issues that we face in the $21^{\text {st }}$-century is that technology is currently outstripping our ability to use it. In other words, we are creating computers and other technological systems that we can not figure out how to use as quickly as they created. Computer gets faster and faster, but the human beings who have to use them do not" (Wright, 2015:11). Teknologi adalah salah satu tantangan bagi manajemen sumber daya manusia. Peranan teknologi modern pada MSDM sangat kuat, misalnya teknologi informasi yang telah mengubah segalanya:"Another HRM challenge is the technology. Technology means the ways and methods of living and work. These methods and ways have been changed by the modern technology. The information technology has changed everything. It touches such information and ideas which are essential for the economy. Economy has large amount of capital that resides in people. There are some other assets which are physically 


\section{Kebijakan: Jurnal Ilmu Administrasi \\ Volume 10, Nomor 1, Januari 2019 \\ E-ISSN: 2656-2820 \\ P-ISSN 1829-5762}

owned by the people but Human Resource as an essential asset has no true ownership. The only way to develop and retain such human resources is create such an environment which compete them to stay in the organization and it is a main challenge for HRM. " (Hashim dan Hameed, 2012:46).

Contoh pendekatan teknologi pada manajemen sumber daya manusia , misalnya perekrutan dengan menggunakan media sosial, penggunaan aplikasi bersama antara atasan dan staf, dan untuk menilai nilai pegawai di organisasi:"Human resources will also have the responsibility of updating their technology approaches. For example, they will change their recruiting approach to use social media to find the right candidates for job opportunities. They will update technology policies to include conduct and safeguards for IT property, and expand the use of shared applications between employers and staff. In addition, they will be able to link an employee's performance with a company's business goals to assess an employee's value in the company."(Ramjee, tanpa tahun:1).

\section{Globalisasi}

Globalisasi berdampak besar terhadap berbagai sektor, terutama sektor ekonomi:"In this period the global economy has been through an exceptional business cycle, going from growth with high pressure on existing capacity to financial crisis, downturn and serious slump in 2010. In the same period globalization has intensified pressure on markets and firms. Private sector firms find themshelves in rapidly changing environment with increasing competition that call for development of internal and external resources and capabilities to manage the challenges"(Nielsen, 2016: 10). Di Kawasan ASEAN terjadi liberalisasi perdagangan dengan dibentuknya MEA sehingga kompetisi pasar, termasuk pasar tenaga kerja, menjadi lebih kompetitif. Sumber daya manusia anggota ASEAN dapat bekerja di negara-negara anggota ASEAN termasuk di Indonesia. Sementara peringkat sumber daya manusia Indonesia di bawah beberapa sumber daya manusia negara Singapura, Brunei Darussalam, Malaysia, dan Thailand. Sebagai salah satu upaya untuk meningkatkan kualitas sumber daya manusia adalah melalui manajemen sumber daya manusia modern yang profesional, antara lain melalui pengembangan model manajemen sumber daya manusia "halus" seperti melalui pelatihan atau workshop.

Dampak globalisasi, maka telah terjadi sebuah fenomena peralihan jenis pekerjaan di Amerika beralih ke sektor jasa dan telekomunikasi:"A major change is the shift of jobs from manufacturing and agriculture to service industries and telecommunications" (Mathis dan Jackson, 2005: 4). Hal ini berdampak pula terhadap negara berkembang maupun pada negara-negara yang belum berkembang, yaitu pengalihan pekerjaan dengan alasan bahwa upah kerja di negara-negara belum berkembang lebih murah:"The less skilled manufacturing assembly jobs have been shifting from the higher wage, developed economies in the United States and Western Europe to developing countries in Eastern Europe, Chine, Thailand, Mexico, and the Phillipines" (Mathis dan Jackson, 2005: 5). Dampak lainnya adalah mendorong beberapa organisasi untuk melakukan restrukturisasi agar dapat bersaing. Termasuk melakukan penggabungan dengan organisasi lain:"Many organizations have restructured in the past few years in order to become more competitive. Also, mergers and acquisition of firms inthe same industries have been made to ensure global competitiveness. The "mega-mergers" in the banking, petroleum, and telecommunications industries have been very visible, but mergers and acquisition of firms in many other industries have increased in recent years"(Mathis dan Jackson, 2005: 10). Dalam konteks manajemen sumber daya manusia modern, peranan manusia adalah sebagai investasi atau aset: "The strategic role of HR management emphasizes that the people in an organization are valuable resources representing significant organizational investment. For HR to play a strategic role it must focus on the longer term implications of HR issues" (Mathis dan Jackson, 2005: 16). Konsep manajemen sumber daya manusia 


\section{Kebijakan: Jurnal Ilmu Administrasi \\ Volume 10, Nomor 1, Januari 2019 \\ E-ISSN: 2656-2820 \\ P-ISSN 1829-5762}

modern mengenai sumber daya manusia harus dipandang dari banyak aspek, diantaranya teknologi: "Human resources must be viewed in the same context as the financial, technological, and other resources that are managed in organizations" (Mathis dan Jackson, 2005: 16). Pada dasarnya praktek manajemen sumber daya manusia membutuhkan gabungan dua aspek ketrampilan dan pengetahuan yang jelas: "It is widely accepted that human resources management requires a mix of skills in working with tacit and explicit knowledge" (Soliman dan Spooner, 2000: 338).

\section{Peluang dan Tangtangan Sumber Daya Manusia Dalam Era Disrupsi}

Saat ini sedang popular istilah disrupsi ( dari asal kata disrupt = mengacaukan; mengganggu. disruption= gangguan; kekacauan. disruptive= yang mengacaukan; yang mengganngu). Disrupsi adalah sebuah model yang diciptakan oleh Clay Christensen pada tahun 1997 di Amerika. Menurut Christensen inovasi disrupsi adalah:" It is a theory of competitive response"(Denning, 2016: 10-11). Inovasi disrupsi (disruptive innovation) adalah sebuah isu hangat yang banyak dibicarakan di kalangan pebisnis. Seperti dinyatakan oleh Paetz:" Disruptive innovation is the single most talked about business concept today, especially in the technology business." (Paetz, 2014:3). Sifat dari inovasi disrupsi adalah menawarkan keunggulan-keunggulan lain, misalnya proses lebih sederhana, lebih menyenangkan, dan lebih menarik bagi masyarakat-masyarakat baru. Menurut Paetz inovasi disrupsi memproduksi produk-produk yang bersifat "inferior "(rendah mutunya) dan "underperform" (berkinerja rendah) jika dibandingkan dengan produk yang sudah ada. Sebenarnya istilah di atas tidak sepenuhnya tepat tetapi hanya untuk membandingkan dengan produk yang sudah laku di pasar. Tujuan memproduksi produk hasil inovasi disrupsi adalah untuk "mengganggu" pasar yang ada, yaitu pasar yang dikuasai oleh petahana (incumbent). Salah satu contoh pasar yang diganggu adalah moda transportasi taxi.

Penggunaan telepon pintar (smart phone) yang semakin marak,seperti jasa transportasi moda transportasi on line, seperti Uber, Grab dan Gojek, menjadi lebih mudah dan lebih murah. Moda transportasi on line tersebut telah melakukan disrupsi terhadap moda transportasi petahana dengan cara menawarkan proses pemesanan dan pembayaran yang lebih praktis, biaya lebih murah, dan sekaligus menciptakan pasar baru. Inovasi disrupsi tidak terbatas pada bisnis teknologi tetapi berkembang pada sektor-sektor lainnya, termasuk praktek-praktek MSDM modern yang menggunakan produk-produk teknologi hasil disrupsi. Sehingga praktek manajemen sumber daya manusia lebih praktis, efisien dan efektif. Misalnya, di dalam rangka melaksanakan pengembangan sumber daya manusia melalui program pelatihan atau workshop sumber daya manusia dengan menggunakan media teknologi baru dalam menyampaikan materi atau berkomunikasi. Dengan demikian, prosesnya bisa lebih cepat dan jangkauannya lebih luas apabila dibandingkan program pelatihan dan workshop sebelumnya.

Terdapat fenomena universal di kalangan pemerintahan di dunia dalam menghemat anggaran serta mendorong para pemimpin dengan tantangan untuk bekerja lebih banyak tapi dengan biaya yang lebih sedikit:"In the wake of the budgetary austerity facing most governments around the world, leaders are faced with the challenge to "do more with less" ( Eggers et al., 2012:17). Artinya bahwa para pemimpin dituntut untuk melihat sektor publik dengan cara baru, antara lain dengan menggunakan inovasi disrupsi. Contohnya pelayanan publik mengenai pajak, SIM, paspor, kesehatan yang menggunakan sistem on line, yaitu sebuah sistem hasil disrupsi sistem sebelumnya yang berbentuk pelayanan langsung di tempat pelayanan. Sistem on line telah berhasil memangkas biaya, waktu, jumlah petugas dan sebagainya. Beberapa negara menggunakan produk elektronik dalam melakukan monitoring agar dapat memangkas biaya operasional:"Several governments have made concerted efforts to spur the more rapid adoption of electronic monitoring." (Eggers et al., 2012:20). 


\section{Manajemen Sumber Daya Manusia Dalam Era Disrupsi: Sebuah Potensi Sekaligus Tantangan}

Selama ini praktek manajemen sumber daya manusia telah mengalami banyak perubahan sekaligus merubah dari manajemen sumber daya manusia tradisional menjadi yang berorientasi modern pada abad ke-21. Perubahan tersebut seperti yang dinyatakan berikut: "Human Resource Management has changed over the past 40 years, taking us from the past traditional view of HRM to the present $21^{\text {st }}$ - century view of HRM" (Wright, 2015 :6). Disamping itu, peranan pemimpin organisasi pun secara langsung akan mengalami perubahan, bersama-sama dengan para pemimpin yang lainnya dalam sebuah organisasi, sebagai upaya untuk meningkatkan pendapatan dan laba organisasi:"Today"s Human Resource Manager is no longer running an organizational cost center. Their function, along with all other managers within the organization, is to improve organizational revenues and profits-to be a profit center" (Wright, 2015:7). Namun dalam prakteknya terdapat beberapa masalah yang dihadapi oleh pemimpin di era modern dalam mengahadapi kesiapan sumber dara manusia, antara lain kendala pengetahuan dan teknologi:“....some of the issues facing today"s HR Managers, including challenges, the strategic view, technology and knowledge, changing labour demographics, and productivity and competitiveness through HRM"' (Wright, 2015:8).

Pada dasarnya peran manajemen sumber daya manusia dalam konteks abad ke-21 adalah lebih menekankan terhadap peranan sumber daya manusia - yaitu orang-orang yang terlibat dalam sebuah organisasi - sebagai salah satu sarana utama untuk menciptakan keunggulan kompetitif bagi organisasinya: "One simple fact is that, in the $21^{\text {st }}$-century organization, human resources- the people within an organization- are one of the primary means of creating a competitive advantage for the organization, because management of human resources affects performance" (Wright, 2015:5). Damapaknya adalah model kontrol manajemen organisasi seperti di bawah ini sudah tidak berlaku lagi pada manajemen sumber daya manusia abad ke-21: "In the $21^{\text {st }}$-century organization, the primary HRM function is no longer just ensuring that the company has (1) the correct number of employees with the levels and type of skills the organization requires and (2) control systems to make sure employees are working toward the achievement of the goals in the strategic plant."(Wright, 2015:10).

Perspektif manajemen sumber daya manusia modern dan abad ke-21 berbeda dengan manajemen sumber daya manusia sebelumnya - seringkali disebut sebagai manajemen personalia karena berbagai factor internal maupun eksternal. Dalam praktek manajemen sumber daya manusia sebelumnya atau tradisional pegawai tidak dilibatkan dalam aktivitas bisnis organisasi. Secara garis besarnya praktek manajemen sumber daya manusia tradisional menempatkan manusia hanya sebagai "pegawai pendukung" sebuah organisasi: "Traditionally, HR has been viewed as the "employee advocate" in organizations who do not understand the business realities of the organizatios and do not contribute measurably to the strategic success of the business"(Mathis dan Jackson, 2005: 14).

\section{SIMPULAN}

Pada kenyataannya manajemen sumber daya manusia telah mengalami banyak perubahan, khususnya perubahan dari manajemen sumber daya manusia tradisional menuju manajemen sumber daya manusia modern yang menyongsong abad ke-21. Perubahan ini didorong oleh banyak faktor, diantaranya dinamika dan kompleksitas lingkungan luar seperti perkembangan teknologi yang cepat. Bagaimanapun, produk teknologi adalah salah satu unsur utama yang mendorong perkembangan manajemen sumber daya manusia, termasuk di dalam melakukan perubahan menuju manajemen sumber daya manusia abad ke-21. Praktek MSDM modern sehari-hari tidak terlepas dari produkproduk teknologi modern, misalnya penggunaan internet dan intranet. Keduanya adalah sebuah kebutuhan pokok yang tidak mungkin diabaikan. Sektor teknologi mengalami perkembangan yang sangat pesat, misalnya terjadi disrupsi pada tahun 1990-an. Dengan adanya disrupsi telah 


\section{Kebijakan: Jurnal Ilmu Administrasi \\ Volume 10, Nomor 1, Januari 2019 \\ E-ISSN: 2656-2820 \\ P-ISSN 1829-5762}

menyebabkan usia produk teknologi semakin singkat, menyebabkan produk sebelumnya menjadi tidak terpakai, biaya operasional produk lama menjadi tinggi dan tidak ekonomis, dan produk-produk lama menjadi usang. Contoh yang paling jelas dan tepat adalah teknologi komputer yang semakin canggih kemampuannya dan praktis penggunaannya. Teknologi komputer, misalnya internet dan intranet adalah bagian yang tidak terpisahkan dalam praktek manajemen sumber daya manusia modern.

Era disrupsi adalah sebuah peluang sekaligus tantangan terhadap praktek manajemen sumber daya manusia modern. Peluangnya adalah dalam rangka meningkatkan kinerja pemimpin serta kesiapan pegawai sebagai sumber daya manusia menuju kinerja terbaik, meningkatkan sebuah organisasi/organisasi menjadi lebih efisien, efektif dan kompetitif. Termasuk menghadapi tantangantantangan di era global. Sedangkan tantangan lainnya di dalam implementasi manajemen sumber daya manusia yang berbasis teknologi disebabkan sistem teknologi canggih membutuhkan biaya besar dan membutuhkan sumber daya manusia yang memiliki kemampuan menggunakan produk-produk teknologi modern. Peralihan teknologi ini merupakan sebuah paradigma baru dalam manajemen sumber daya manusia kita. Sehingga prosesnya tidak semudah yang dibayangkan namun ada kesenjangan, terutama di sektor sumber daya manusia . Apalagi jika dikaitkan dengan fenomena yang terjadi pada sumber daya manusia ketenagakerjaan di Amerika saat ini. Menurut Cindy Wright (2015) bahwa sebagian besar mereka bekerja seperti ini:" They don " $t$ work with their hands; they work with their heads".

\section{DAFTAR PUSTAKA}

Christensen, M., Clayton \& Raynor, E., Michael. (2003). The Innovator's Solution. Harvard Business Scholl Press: Boston, Massachusetts, America.

Cowden, J., Birton., \& Alhorr, S., Hadi. (2013). Disruptive innovation in multinational enterprises", Multinational Business Review, Vol. 21, Issue: 4, pp.358-371.

Denning, Stephen. (2016). Christensen updates disruption theory. Strategy \& Leadership, Vol. 44 (2), pp. 10-16.

Eggers, William., Baker, Laura., Gonzales, Ruben., and Vaughn, Audrey. (2012). Disruptive innovation: a new model for public sector services. Strategy \& Leadership, Vol. 40 (2), pp. 1724.

Habtay, R., Salomon., \& Holmèn, Magnus. ( -). From disruptive technology to disruptive business model innovation: In need for an integrated conceptual framework. Unpublished Paper. School of Economic and Business Sciences, University of Witwatersrand: South Africa.

Hashim, Muhammad., \& Hameed, Fazal. 2012. Human Resource Management in 21st Century: Issues \& Challenges \& Possible Solutions to Attain Competitiveness. International Journal of Academic Research in Business and Social Sciences, Vol. 2 (9), pp. 44-52.

Jimenez, Jimenez., Daniel. \& Valle, Sanz., Raquel. (2007). Managing human resources in order to promote knowledge management and technical innovation. Management Research, Vol. 5, No. 2, pp. 83-100.

Knight, J., Daniel. (2005). Three trips around the innovation track: an interview with Clayton Christensen. Strategy \& Leadership, Vol. 33(4) pp. 13-19.

Madsen, Stjernholm., Arne., \& Ulhoi, P., Madsen. (2005). Technology innovation, human resources and dysfungsional integration. International Journal of Manpower, Vol. 26, No. 6, pp. 488-500.

Madjdi, Farsan., \& Hüsig, Stefan. (2011). The heterogeneity of incumbents' perceptions and response strategies in the face of potential disruption. Foresight, Vol. 13 No. 5 pp. 14-33. 


\section{Kebijakan: Jurnal Ilmu Administrasi \\ Volume 10, Nomor 1, Januari 2019 \\ E-ISSN: 2656-2820 \\ P-ISSN 1829-5762}

Mathis, L., Robert. \& Jackson, H., John. (2005). Eleventh Eds. Thomson Business \& Proffesional Publishing.

Nielsen, Peter. (2016). Managing Human Resources Learning for Innovation. $1^{\text {st }}$ ed. Bookboon.com.

Paetz, Paul. (2014). Disruptive by Design. How to Create Products that Disrupt and then Dominate Markets. Apress: New York City,USA.

Ramjee, Priti. (tanpa tahun). Major Trends in Human Resources in the 21st Century. Didapatkan kembali dari:https://work.chron.com/major-trends-human-resources-21st-century-20735.html. Diakses tanggal 28 Juli 2018.

Sevilla, G., Concuelo., Ochave, A., Jesus., Punsalan, G., Twila., Regala,P., Bella., \& Uriarte,G., Gabriel. (1993). Pengantar Metode Penelitian. Penerbit Universitas Indonesia: Jakarta.

Soliman, Fawzy., \& Spooner, Keri. (2000). Strategies for implementing knowledge management: role of human resources management. Journal of Knowledge Management, Vol. 4 No. 4, pp. 337345 .

Wright, Cindy. (2015). $21^{\text {st }}$-Century Human Resource Management Strategic Planning and Legal Issues. SAGE Publications Inc. : California, USA.

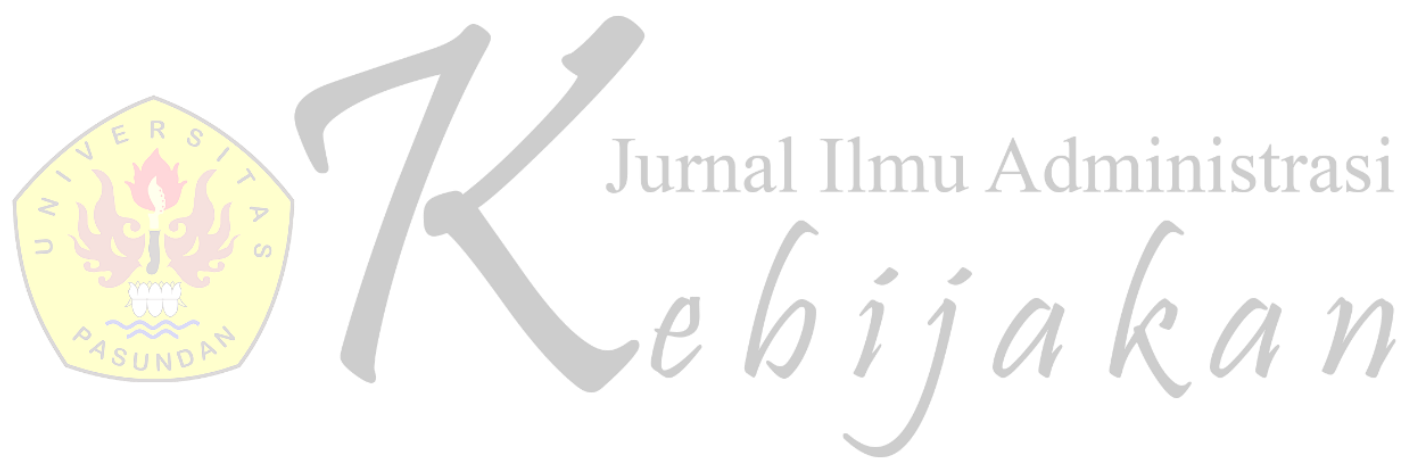

